\title{
GUT MICROBIOTA OF HEALTHY NEWBORNS: NEW DIAGNOSTIC TECHNOLOGIES — NEW OUTLOOK ON THE DEVELOPMENT PROCESS
}

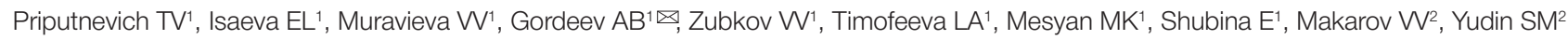

${ }^{1}$ National Medical Research Center for Obstetrics, Gynecology and Perinatology named after Academician V. I. Kulakov, Moscow, Russia

${ }^{2}$ Center for Strategic Planning and Management of Medical and Biological Health Risks, Moscow, Russia

Currently, there are no criteria allowing to adequately assess composition and volume of the newborns' gut microbiota, which prevents early detection of the pathological processes and appropriate intervention. This study aimed to apply the methods of culturomics, proteomics and molecular genetic technologies to investigate the development of gut microbiota in healthy newborns delivered in the city of Moscow both vaginally and through a cesarean section. We examined 66 children, 33 of them delivered vaginally and 33 by cesarean section. The luminal bacterial flora samples were collected on the 1st, 7 th and 30 th days of life. There were 136 species of microorganisms belonging to 40 genera identified. We established that cesarean section slows down normal development of the gut microflora: through the follow-up period (1 month of life), gut microbiocenosis in such children did not yield the results on par with those registered in children born vaginally. Bifidobacteria were significantly more common in the vaginal delivery group: $84 \%$ of $10^{9}-10^{12} \mathrm{CFU} / \mathrm{g}$ versus $33 \%$ of $10^{5}-10^{12} \mathrm{CFU} / \mathrm{g}$ in the cesarean section group. At the same time, the former group had significantly less clostridia ( $33.3 \%$ and $65.4 \%$, respectively) and lactose-negative Escherichia coli strains (2.4 and $19.4 \%$, respectively) than the latter group.

Keywords: microbiota, newborns, gut microbiota

Author contribution: Priputnevich TV — study planning, organization of microbiological tests, data interpretation; Isaeva EL and Muravieva W — conducting microbiological tests, draft authoring: Gordeev AB — data analysis and interpretation; Zubkov W — study planning, feces samples collection organization; Timofeeva LA and Mesyan MK — feces collection; Shubina E — sequencing; Makarov W and Yudin SM — study planning.

Compliance with ethical standards: the study was approved by the Ethics Committee of National Medical Research Center for Obstetrics, Gynecology and Perinatology named after Academician V. I. Kulakov (meeting minutes № 4 of April 12, 2018). Parents of all children included in the study signed the voluntary informed consent to participate in the study.

Correspondence should be addressed: Alexey B. Gordeev

Akademika Oparina, 4, Moscow, 117997; gordeew@vega.protres.ru

Received: 28.08.2019 Accepted: 11.09.2019 Published online: 28.09.2019

DOI: $10.24075 /$ brsmu.2019.063

\section{МИКРОБИОТА КИШЕЧНИКА ЗДОРОВЫХ НОВОРОЖДЕННЫХ ДЕТЕЙ: НОВЫЕ ТЕХНОЛОГИИ ДИАГНОСТИКИ - НОВЫЙ ВЗГЛЯД НА ПРОЦЕСС СТАНОВЛЕНИЯ}

Т. В. Припутневич ${ }^{1}$, Е. Л. Исаева', В. В. Муравьева ${ }^{1}$, А. Б. Гордеев ${ }^{1} \bowtie$, В. В. Зубков ${ }^{1}$, Л. А. Тимофеева', М. К. Месян ${ }^{1}$, Е. Шубина ${ }^{1}$, В. В. Макаров², С. М. Юдин²

${ }^{1}$ Национальный медицинский исследовательский центр акушерства, гинекологии и перинатологии имени академика В. И. Кулакова, Москва, Россия

2 Центр стратегического планирования и управления медико-биологическими рисками здоровью, Москва, Россия

В настоящее время не существует критериев адекватной оценки качественного и количественного состава микробиоты кишечника новорожденных детей что не дает возможности выявить на ранних сроках патологический процесс и скорректировать его. Целью исследования было изучить становление микробиоты кишечника у здоровых новорожденных в городе Москве, рожденных самопроизвольно и путем операции кесарева сечения, с помощью методов культуромики, протеомики и молекулярно-генетических технологий. Обследовано 66 детей: 33 ребенка, рожденных самопроизвольно, и 33 - путем операции кесарева сечения. Образцы просветной микрофлоры собирали на первые, седьмые и 30-е сутки жизни. Выделено 136 видов микроорганизмов, относящихся к 40 родам. Показано, что кесарево сечение тормозит процесс нормального становления микрофлоры кишечника, и в течение изучаемого периода (первого месяца жизни) микробиоценоз кишечника у таких детей не достигает показателей у детей, рожденных самопроизвольно. Статистически достоверно в группе самопроизвольных родов преобладали бифидобактерии (частота их встречаемости в титре $10^{9}-10^{12} \mathrm{KOE} /\ulcorner$ составила 84\% против 33\% при титре $10^{5}-10^{12}$ KOE/Г в группе кесарева сечения). В то же время у детей, рожденных самопроизвольно, по сравнению с детьми, рожденными путем кесарева сечения, отмечена статистически достоверно более низкая частота обнаружения клостридий (33,3 и 65,4\% соответственно) и лактозоотрицательных штаммов Escherichia coli (2,4 и 19,4\% соответственно).

Ключевые слова: микробиота, новорожденные, микробиота кишечника

Информация о вкладе авторов: Т. В. Припутневич - планирование исследования, организация микробиологических исследований, интерпретация данных; Е. Л. Исаева и В. В. Муравьева — проведение микробиологических исследований, подготовка черновика рукописи; А. Б. Гордеев - анализ и интерпретация данных; В.В.Зубков - планирование исследования, организация сбора проб фекалий; Л. А. Тимофеева и М. К. Месян - сбор проб фекалий; Е. Шубина — проведение секвенирования; В. В. Макаров и С. М. Юдин — планирование исследования

Соблюдение этических стандартов: исследование одобрено этическим комитетом НМИЦ АГП им. В. И. Кулакова (протокол заседания № 4 от 12 апреля 2018 г.). Родители всех детей, включенных в исследование, подписали добровольное информированное согласие на участие в исследовании.

$\bowtie$ Для корреспонденции: Алексей Борисович Гордеев

ул. Академика Опарина, д. 4, г. Москва, 117997; gordeew@vega.protres.ru

Статья получена: 28.08.2019 Статья принята к печати: 11.09.2019 Опубликована онлайн: 28.09.2019

DOI: 10.24075/vrgmu.2019.063

Today, the nature of microbial colonization of the human intestine, including that of the newborns, has changed significantly. The reasons are the growing number of complicated pregnancies, stressful situations, poor environmental conditions and uncontrolled intake of antibiotics.
An in-depth study of the gut microbiota that implies application of the methods offered by culturomics, high-tech isolated microorganisms identification (MALDI-TOF MS, 16S rRNA gene sequencing) and metagenomic analysis can yield an expanded outlook of its species diversity. 
Against this background, the currently adopted gut microbiota standards (composition and volume) [1-3] require revision. To date, there are no clearly defined criteria for the newborns' gut microbiota assessment, the criteria that would allow timely interventions addressing the problems detected and early measures arresting pathological processes, such as necrotizing enterocolitis in premature babies. Very few researchers undertook statistical processing of the data describing composition and volume of the newborns' gut microbiota [4, 5].

This study aimed to apply the methods of culturomics, proteomics and molecular genetic technologies to investigate the development of gut microbiota in healthy newborns delivered in the city of Moscow both vaginally and by a cesarean section.

\section{METHODS}

A cohort of healthy full-term newborns was selected for this prospective study. The cohort was randomized by blocks, which yielded two groups of children:

1) group I - 33 children delivered vaginally;

2) group II - 33 children born by caesarean section.

The inclusion criteria were as follows: gestational age 38-40 weeks; Apgar score of 8-9 points (first and fifth minutes of life); body weight over $2800 \mathrm{~g}$. Blood and urine of the newborns were tested for infectious pathologies or other factors that could affect development of the gut microbiota. All children were breastfed; feeding formulas were used in isolated cases only. No mother had a prolonged latency period; 3 women took antibiotics during pregnancy; 4 women had cervical incompetence (6\%). In the surgical delivery cases the women received amoxicillin/clavulanic acid for prevention purposes before and during surgery.

The feces were collected from the newborns three times: on the 1st day, at the end of the 1st week and at the end of the 1st month of life. The samples of meconium obtained during the first bowel movement or feces collected from a sterile diaper and put into a sterile plastic container were delivered to the laboratory within 2 hours; plating was performed immediately upon delivery.

We studied the gut microbiota using an extended range of selective and non-selective culture media. The incubation was done in aerobic, microaerophilic and anaerobic conditions.

Following the generally adopted methods [3, 6], we plated meconium and feces on the following culture media. Isolation of the facultative anaerobic and aerobic microorganisms: Colombian blood agar, Brilliance chromogenic medium, Salmonella Shigella Agar, Sabouraud Dextrose Agar (Oxoid; Great Britain), mannitol salt agar (Himedia; India), Streptococcus agalactiae detection and differentiation medium (CHROMagar; France), Enterococcus Agar, Endo Agar (GITsPM i B; Russia). Lactobacilli culturing: Lactobacillus Agar (GITsPM i B; Russia). Obligate anaerobes isolation: Bifidobacterium Agar (Himedia; India), pre-reduced Schaedler Agar with necessary additives, Anaerobic Agar, Perfringens Agar, Iron Sulphite Agar, Clostridium difficile selective Agar (Oxoid; UK). To culture microaerophiles, we used a $\mathrm{CO}_{2}$ incubator (Jouan; France) with the $\mathrm{CO}_{2}$ concentration of $5 \%$. To culture obligate anaerobes, we used an anaerobic box (Jouan; France) filled with a three-component gas mixture $\left(\mathrm{N}_{2}-80 \%\right.$; $\left.\mathrm{CO}_{2}-10 \% ; \mathrm{H}_{2}-10 \%\right)$. Thioglycol broth (Oxoid; Great Britain) enabled sterility control.

The microorganisms were identified with the help of a MALDITOF AutoFlex III time-of-flight mass spectrometer powered by the MALDI BioTyper v3.0 software (Bruker Daltoniks; Germany). At SCORE > 2.0, the culture was marked as identified on the species level (high probability of identification). At SCORE 1.7 to 2.0, the culture was considered identified at the genus level.

When the SCORE was below 2.0, i.e. the strain was hard to identify, we did the $16 \mathrm{~S}$ rRNA gene sequencing. The ProbaCiTo (DNA-Technology; Russia) reagent set enabled extraction of the DNA. We used two DNA fragments for sequencing: an amplicon of $\sim 40$ bp (positions 339-785 of the 16S rRNA gene) and an amplicon of $\sim 1340$ bp (positions 42-1380 of the 16S rRNA gene). These were amplified using the DTprime detecting amplifier (DNA-Technology; Russia). For sequencing, we employed a 3130 Genetic Analyzer (Applied Biosystems; USA) and used the BigDye ${ }^{\mathrm{TM}}$ Terminator v3.1 Cycle Sequencing Kit (Applied Biosystems; USA) following the protocol provided by the manufacturer. For species identification, the BLAST software package (National Center for Biotechnology Information; USA), freely available on the Internet, was used.

To determine differences in the frequency of occurrence of microorganisms depending on the mode of delivery, we applied the Fisher's exact test during statistical processing of the data. Median and interquartile range were used as descriptive statistics to characterize the degree of microbial contamination.

\section{RESULTS}

At the 1st time point we examined 66 children, 33 in each group. The meconium of every 5th child was sterile; in group II such a situation was observed twice as often as in group I (9 and 4 cases, respectively; $p>0.05$ ). The non-sterile meconia featured diverse microflora (63 species; the average species diversity index was 3.8 species per child). The bacteria isolated most often (in $60 \%$ of the vaginally delivered babies, titer of $10^{2}-10^{3} \mathrm{CFU} / \mathrm{g}$, and in $70 \%$ of the cesarean section babies, titer of $10^{2}-10^{4} \mathrm{CFU} / \mathrm{g}$ ) were gram-positive facultative anaerobic microorganisms of 10 genera: Staphylococcus, Streptococcus, Enterococcus, Micrococcus, Gemella, Globicatella, Granulicatella, Rothia; Corynebacterium, Bacillus. It is noteworthy that in $12.2 \%$ of the group II children and in $6.1 \%$ of the group I children we detected Staphylococcus aureus (S. aureus). Escherichia coli, which normally makes up a significant part of the normal intestinal flora, was isolated thrice as often in the vaginally born babies $(24.2 \%$ and $9.1 \% ; p>0.05)$. Same is true about other enterobacteria (27\% and $15 \%$, respectively; $p>0.05)$. Only one baby had Pseudomonas aeruginosa (group II).

Lactobacilli and bifidobacteria play the most important role in the development of the newborn's gut microbiota. These microorganisms were found as early as in the first day of life. The size of the lactobacilli colonies was significantly greater in group I (18\% and 3\%, respectively; $p>0.05)$; the lactobacilli forming those colonies were Lactobacillus crispatus and Lactobacillus jensenii, which are among the dominant species in the vaginal microbiota of healthy women. Bifidobacteria were also isolated more often in the sampled taken from the group I babies ( $9 \%$ and $3 \%$, respectively; $p>0.05)$; the bacteria were Bifidobacterium bifidum, B. longum, B. adolescentis. Only 1 baby (group I) had bacteroids detected in the first day of life. Other anaerobes (veillonella, prevotella and campylobacter) were isolated almost exclusively in group II.

Through the first week of the study, some parents refused to continue participation and some children contracted an infectious disease. Therefore, at the 2 nd time point we examined 52 babies, 25 from group I and 27 from group II.

Compared to the 1st time point, the average species diversity index increased almost 3 -fold and reached 9.4 species per child. As in the first day of life, both groups 
had facultative anaerobic microorganisms (9 genera) detected most often. Their titer increased considerably: in the vaginal delivery group it was $10^{7}-10^{11} \mathrm{CFU} / \mathrm{g}$, in the cesarean section group - $10^{7}-10^{12} \mathrm{CFU} / \mathrm{g}$; the frequency of occurrence was $100 \%$ in both groups. S. aureus became a more common bacterium: we isolated it in $44 \%$ of the group I babies and in $55.6 \%$ of the group II babies. The diversity of enterococci expanded from two to six species: Enterococcus faecalis, E. durans, E. faecium, E. gilvus, E. avium, E. gallinarum. Same as in the first day of life, $E$. faecalis dominated gut microbiota of the majority of participants, colonizing the intestines of $80 \%$ of the group I children and $88.9 \%$ of the group II children.

The range of gram-negative facultative anaerobic bacteria present extended from 6 to 15 species (Enterobacteriaceae). $E$. coli was still detected more often in the vaginally born babies (64\% in group I and $44.4 \%$ in group II; $p>0.05$ ). The frequency of isolation of other enterobacteria was approximately the same in both groups.

The composition of lactobacilli species extended with L. paracasei, L. curvatus, L. gasseri, L. fermentum, L. rhamnosus. It should be noted that the species of lactobacilli dominating vaginal microbiota of healthy women (L. crispatus, L. jensenii $n$ $L$. gasseri) were only found in the group I children.

We registered statistically significant differences in the representation of bifidobacteria. In group I such were detected in $84 \%$ of samples with the titer of $10^{9}-10^{12} \mathrm{CFU} / \mathrm{g}$, and in group II the figure was only $33 \%$, with the titer of $10^{5}-10^{12} \mathrm{CFU} / \mathrm{g}$ $(p<0.05)$. The number of bifidobacteria species grew from 3 to $7: B$. adolescentis, B. breve, B. dentium, B. catenulatum, $B$. bifidum, $B$. Iongum, $B$. animalis. Some were detected only on one of the groups: $B$. adolescentis and $B$. catenulatum (group I exclusively) and $B$. dentium and $B$. animalis (group II exclusively).

By the seventh day of life, microbiota became significantly more diverse, adding 11 new genera of other obligate anaerobes: Bacteroides, Parabacteroides, Veillonella, Clostridium, Fusobacterium, Ruminococcus, Eubacterium, Eggerthella, Actinomyces, Collinsella, Propionibacterium. The bacteroids represented by Bacteroides fragilis, B. ovatus, B. vulgatus, B. uniformis, Parabacteroides distasonis were only detected in children born vaginally. We registered no significant difference in the frequency of detection of clostridia (Clostridium perfringens, C. butyricum, C. innocuum, C. tertium). One baby from group II had $C$. difficile. Veilonella colonies grew larger in both groups.

Thus, by the 7th day of life microbiota of the participants featured significantly more species of various genera, both facultatively anaerobic and obligate anaerobic. Bifidobacteria, lactobacilli and bacteroids were prevalent in group I.

At the 3rd time point we examined 50 children, 24 from group I and 26 from group II. The average species diversity index was 9.4 species per child. As in the earlier periods, grampositive facultative anaerobic bacteria (7 genera) were the most common. The frequency of detection of $S$. aureus remained largely unchained compared to the 7th day in group I (58.3\%) and significantly increased in group ॥ (76.9\%). There were 2 new species of enterococci detected: E. casseliflavus and E. raffinosus.

As for the composition of gram-negative facultative anaerobic microflora, we isolated 11 Enterobacteriaceae species and 1 species of non-fermenting bacteria, Stenotrophomonas maltophilia. E. coli were still detected more often in the vaginally born babies (75\% in group I and $61.5 \%$ in group $\| ; p>0.05$ ). Samples from the group II children had other enterobacteria slightly more often $(66.7 \%$ and $73 \%$, respectively; $p>0.05)$.

The number of lactobacilli expanded to 15 species with
L. reuteri, L. casei, L. vaginalis, L. brevis, L. helveticus, L. acidophilus; we detected twice as many species in group I. As for the bifidobacteria, there was only 1 new species detected, B. ruminantium. The most common were $B$. longum $(58.3 \%$ in group I and $26.9 \%$ in group II) and B. bifidum (33.3 and 34.6\%, respectively).

The new obligate anaerobes discovered were Sutterella and Peptoniphilus. Except for 1 case, bacteroids (6 species) - B. fragilis, B. thetaiotaomicron, B. vulgatus, B. uniformis, B. cellulosilyticus, Parabacteroides distasonis, - were detected in vaginally delivered babies exclusively.

We started seeing a statistically significant difference in the frequency of detection of clostridia (C. perfringens, C. butyricum, C. tertium, C. ramosum, C. paraputrificum, C. difficile): $33.3 \%$ of children in group I and $65.4 \%$ in group II $(p<0.05)$. There were twice as many species of clostridia in group II. One child from group II had C. difficile.

Candida yeast was found in both groups only on the 30th day of life; less than $10 \%$ of children had them.

Thus, regardless of the method of delivery, on the 30th day of life the gut microbiota featured multicomponent microbial associations of facultative and obligate anaerobes. At the same time, certain differences between obligate and transient microbiota components became obvious. The composition of lactobacilli was more diverse (almost twice as many species) in babies delivered vaginally, the species detected more often in their samples were those inhabiting vagina of healthy women. Bacteroids were predominantly isolated in the same group I children, while clostridia, with greater variety of species, were more peculiar to the $\mathrm{C}$-section babies. The conditionally pathogenic facultative anaerobes (S. aureus and enterobacteria, with the exception of $E$. coli) more often colonized children by a cesarean section.

The hemolytic strains of Enterococcus sp. and E. coli occurred with the same frequency in both groups: Enterococcus sp. - 8.3\% in each group, and E. coli - 9.5 and $9.7 \%$, respectively. Lactose-negative strains of $E$. coli were isolated in the group II children 8 times more often than in group I, which is a significant difference (19.4 and $2.4 \%$, respectively; $p<0.05$ ).

Overall, we isolated and identified 136 species of microorganisms of 40 genera: Staphylococcus, Streptococcus, Corynebacterium, Micrococcus, Enterococcus, Rothia, Bacillus, Neisseria, Haemophilus, Gemella, Globicatella, Granulicatella, Escherichia, Klebsiella, Raoultella, Kluyvera, Enterobacter, Citrobacter, Proteus, Morganella, Pantoea, Pseudomonas, Stenotrophomonas, Candida, Lactobacillus, Bifidobacterium, Bacteroides, Propionibacterium, Veillonella, Clostridium, Ruminococcus, Eggertella, Fusobacterium, Eubacterium, Actinomyces, Collinsella, Prevotella, Campylobacter, Peptoniphilus, Sutterella.

Identification of genera of 36 isolated bacteria (SCORE < 2.0) required $16 \mathrm{~S}$ rRNA sequencing. In most cases, sequencing results confirmed findings of the MALDI-TOF MS study. Only for 5 isolates $16 \mathrm{~S}$ rRNA gene sequencing was the only method allowing reliable identification. In some cases with closely related microorganisms it was not possible to identify the species neither with sequencing nor with MALDI-TOF MS. These species were: Bifidobacterium kashiwanohense/ Bifidobacterium pseudocatenulatum/Bifidobacterium catenulatum, Lactobacillus casei/Lactobacillus paracasei, Actinomyces naes/undii/Actinomyces viscosus, Actinomyces radingae/ Actinomyces ihumii. Eleven isolates produced discrepancies in identification: for 7 of them, it was impossible to find out the genera correctly with the help of MALDI-TOF MS, and 4 presented problems with the species identification. 
The table presents generalized data on the frequency of occurrence and degree of microbial contamination of the newborns' intestines depending on the method of delivery; the data allows preliminary characterization of the indicators peculiar to microflora of healthy children.

\section{DISCUSSION}

Until recently, it was believed that the gastrointestinal tract of a newborn remains sterile for the first 10-20 $\mathrm{h}$ (aseptic phase) [7], and the bacteria first to colonize the intestines of a vaginally delivered child are the lactobacilli from the mother's vaginal microflora [8-11]. However, some experimental research efforts gave rise to another point of view [12]. According to the recently published data, a fetus receives foundation of the gut microflora through bacterial translocation from his mother during the second half of pregnancy; some researchers argue sterility around the fetus [13-15]. In our study, we found that the meconium collected during first defecation in the first hours of life was unsterile in 53 of 66 newborns (80\%), which does not exclude intrauterine colonization.

The published works state that the first hours and the first day of life are the time of active colonization, when the colonies of Escherichia coli, enterococci develop rapidly; the period is known as the growing colonization stage and its course is independent from the degree of maturity, perinatal fetus development conditions and the type of feeding [16-19]. The enterobacteria titer during that period reaches $10^{9} \mathrm{CFU} / \mathrm{g}$ of feces [20], and the anaerobes - bifidobacteria, lactobacilli, bacteroids - are usually absent [21]. According to the data we obtained, the first hours of life were the time when the intestines were mainly colonized by the gram-positive cocci (Staphylococcus spp, Streptococcus spp), and the cesarean section babies had larger colonies than the vaginally delivered children (frequency of occurrence 70 and $60.6 \%$, titers up to $10^{4}$ and $10^{3} \mathrm{CFU} / \mathrm{g}$, respectively). During this period, enterobacteria and obligate anaerobic microorganisms were discovered rarely and with low titers. At the same time, already in the first hours of life microbiota of the vaginally born children featured more bifidobacteria and lactobacilli than that of babies delivered by a Caesarean section: 9 and 3\%, respectively, and 18 and 3\%, respectively. Bacteroids were detected only in $3 \%$ of children born vaginally. A possible reason for the discrepancy between our data and the results demonstrated by other authors is the fact that we aimed to obtain the sample biomaterial directly during the first act of defecation of the newborn.

Table. Frequency of occurrence, median and interquartile range of the degree of contamination of feces with microorganisms

\begin{tabular}{|c|c|c|c|c|c|c|}
\hline \multirow{2}{*}{ Characteristic } & \multicolumn{2}{|c|}{$1^{\text {st }}$ day of life $(n=66)$} & \multicolumn{2}{|c|}{$7^{\text {th }}$ day of life $(n=52)$} & \multicolumn{2}{|c|}{$1^{\text {st }}$ month of life $(n=50)$} \\
\hline & Vaginal delivery & Cesarean section & Vaginal delivery & Cesarean section & Vaginal delivery & Cesarean section \\
\hline \multicolumn{7}{|c|}{ E. coli } \\
\hline Frequency of occurrence & $24 \%$ & $9 \%$ & $64 \%$ & $44.40 \%$ & $70.80 \%$ & $61.50 \%$ \\
\hline Median (CFU/g) & $10^{2}$ & $10^{2}$ & $10^{8}$ & $10^{9}$ & $10^{9}$ & $10^{9}$ \\
\hline Interquartile range (CFU/g) & $10^{2}$ & $10^{2}-10^{3}$ & $10^{8}-10^{9}$ & $10^{8}-10^{10}$ & $10^{8}-10^{10}$ & $10^{8}-10^{10}$ \\
\hline \multicolumn{7}{|c|}{ Other enterobacteria } \\
\hline Frequency of occurrence & $27 \%$ & $15 \%$ & $68 \%$ & $66.70 \%$ & $66.70 \%$ & $73 \%$ \\
\hline Median (CFU/g) & $10^{3}$ & $10^{3}$ & $10^{9}$ & $10^{9}$ & $10^{9}$ & $10^{9}$ \\
\hline Interquartile range (CFU/g) & $10^{2}-10^{4}$ & $10^{2}-10^{3}$ & $10^{8}-10^{10}$ & $10^{9}-10^{10}$ & $10^{8}-10^{10}$ & $10^{9}-10^{10}$ \\
\hline \multicolumn{7}{|c|}{ Gram-positive facultative anaerobic and aerobic bacteria } \\
\hline Frequency of occurrence & $60.60 \%$ & $70 \%$ & $100 \%$ & $100 \%$ & $100 \%$ & $100 \%$ \\
\hline Median (CFU/g) & $10^{2}$ & $10^{2}$ & $10^{8}$ & $10^{9}$ & $10^{8}$ & $10^{9}$ \\
\hline Interquartile range (CFU/g) & $10^{2}$ & $10^{2}-10^{3}$ & $10^{8}-10^{10}$ & $10^{8}-10^{10}$ & $10^{7}-10^{9}$ & $10^{7}-10^{9}$ \\
\hline \multicolumn{7}{|c|}{ Bifidobacteria } \\
\hline Frequency of occurrence & $9 \%$ & $3 \%$ & $84 \%$ & $33 \%$ & $83.30 \%$ & $53.80 \%$ \\
\hline Median (CFU/g) & $10^{2}$ & $10^{2}$ & $10^{11}$ & $10^{10}$ & $10^{11}$ & $10^{10}$ \\
\hline Interquartile range (CFU/g) & $10^{2}-10^{3}$ & $10^{2}$ & $10^{9}-10^{11}$ & $10^{6}-10^{11}$ & $10^{10}-10^{12}$ & $10^{10}-10^{11}$ \\
\hline \multicolumn{7}{|c|}{ Lactobacilli } \\
\hline Frequency of occurrence & $18 \%$ & $3 \%$ & $28 \%$ & $37 \%$ & $58.30 \%$ & $69 \%$ \\
\hline Median (CFU/g) & $10^{2}$ & $10^{2}$ & $10^{8}$ & $10^{8}$ & $10^{8}$ & $10^{8}$ \\
\hline Interquartile range (CFU/g) & $10^{2}$ & $10^{2}$ & $10^{6}-10^{10}$ & $10^{6}-10^{10}$ & $10^{5}-10^{10}$ & $10^{7}-10^{10}$ \\
\hline \multicolumn{7}{|c|}{ Bacteroids } \\
\hline Frequency of occurrence & $3 \%$ & 0 & $32 \%$ & 0 & $25 \%$ & $3.80 \%$ \\
\hline Median (CFU/g) & $10^{2}$ & 0 & $10^{9}$ & 0 & $10^{10}$ & $10^{9}$ \\
\hline Interquartile range (CFU/g) & $10^{2}$ & 0 & $10^{9}-10^{11}$ & 0 & $10^{10}$ & $10^{9}$ \\
\hline \multicolumn{7}{|c|}{ Clostridia } \\
\hline Frequency of occurrence & 0 & 0 & $32 \%$ & $40.70 \%$ & $33.30 \%$ & $65.40 \%$ \\
\hline Median (CFU/g) & 0 & 0 & $10^{7}$ & $10^{9}$ & $10^{10.5}$ & $10^{9.5}$ \\
\hline Interquartile range (CFU/g) & 0 & 0 & $10^{6}-10^{9}$ & $10^{6}-10^{10}$ & $10^{6}-10^{11}$ & $10^{8}-10^{10}$ \\
\hline
\end{tabular}


Further on, healthy babies have anaerobic and facultative anaerobic components of their microflora grow actively, the volumes reaching $10^{5}-10^{7} \mathrm{CFU} / \mathrm{g}$ [15]. By the 6th day, aerobic and anaerobic parts of the microflora become balanced, then bifidobacteria and lactobacilli begin to develop rapidly and by the 2nd month of life they reach $10^{9}-10^{10} \mathrm{CFU} / \mathrm{g}$. According to other researchers, days 3-5 mark the beginning of the microflora transformation stage, which results in bifidobacterial flora replacing other microorganisms. This is when bifidobacteria become the core (resident) microflora of the intestines [22-24]. The bifidoflora grows dominant by the 5-20th day of life [25]. Our discoveries are different: the total number of microorganisms increases, reaching $10^{10-12} \mathrm{CFU} / \mathrm{g}$. This suggests that the facultative aerobic and obligate anaerobic components of the microbiota also achieve balance by the first week of life, but there are more various microorganisms colonizing the intestines. Another fact deserving a special note is that in the group II babies bifidobacteria did not colonize the gut actively while obligate anaerobes prevailed there (mainly veilonella, clostridia).

By the end of 1st month of life, both groups had the anaerobic part of microbiota taking leading positions; the dominant species were those of bifidoflora. Nevertheless, we detected bifidobacteria only in half of the babies delivered by the caesarean section, while in the vaginally born babies this indicator reached $83 \%$.

The B. longum subsp. infantis, B. animalis subsp. lactis, B. breve, $B$. bifidum bacteria peculiar to the first year of life produce anti-inflammatory effect and contribute to the development of the Th1 immune response. In adults, the predominant strains are B. longum subsp. Iongum,
B. adolescentis, B. pseudocatenulatum; they promote the Th2 immune response and prevail in the gut microbiota in case of obesity [24]. Besides, the genome of B. longum subsp. infantis has a cluster that encodes the synthesis of enzymes (sialidase, fucosidase, $\mathrm{N}$-acetyl- $\beta$-hexosaminidase and $\beta$-galactosidase) capable of breaking down oligosaccharides to monosaccharides. [25]. Throughout life, bifidoflora remains prevailing and sterile, while other representatives of the obligate microflora can trigger a disease under certain conditions [13]. Our study revealed that it is not the most useful bifidobacteria that dominate the microbiota of the C-section newborns; in particular, they are not able to break down lactose (B. animalis, B. dentium, B. ruminantium).

\section{CONCLUSIONS}

Our results confirm that surgical delivery inhibits the normal process of gut microbiota development to a certain extent. In the future, we plan to continue accumulating information about the state of microbiota in this category of children and expand the scope of our research to include premature babies in order to determine the criteria reflecting normal gut microbiota of healthy full-term newborns. This study allowed establishing, and in the future - replenishing the collection of lactobacilli and bifidobacteria isolated from healthy full-term newborns with the aim to identify bacteria candidates for probiotic strains. Timely adequate assessment of the newborn's microbiota composition against the key biomarkers will allow targeted prevention of the immediate and long-term consequences of perinatal pathology in full-term and premature infants by prescribing an adequate composition of probiotics.

\section{References}

1. OST 91500.11.0004-2003. Protokol vedeniya bol'nykh. Disbakterioz kishechnika. Utv. Prikazom MZ RF № 231 OT 09.06.2003. Moscow, 2003, 173 p.

2. Metodicheskiye rekomendatsii "Bakteriologicheskaya diagnostika disbakterioza kishechnika" Minzdrav RSFSR. 1977.

3. Metodicheskiye rekomendatsii "Mikrobiologicheskaya diagnostika disbakterioza kishechnika". Moskva, 2007.

4. Gronlund MM. Arvilommi H, Kero P, Lehtonen OP, Isolauri E. Importance of intestinal colonization in the maturation of humoral immunity in early infancy: a prospective follow up study of healthy infants aged 0-6 months. Arch Dis Child Fetal Neonatal. 2000; 83 (3): 186-92.

5. Levanova LA. Mikroekologiya kishechnika zhitelej Zapadnoj Sibiri, korrekciya disbioticheskih sostoyanij [dissertation]. M., 2003.

6. Shcherbakov PL, Nizhevich AA, Loginovskaya W, Shcherbakova MYu, Kudriavtseva LV, Mitrokhin SD, et al. Mikroekologiya kishechnika u detey i yeye narusheniya. Farmateka. 2007; (14): 28-34.

7. Akoyev YuS. Funktsional'nyye osobennosti nedonoshennykh detey $\checkmark$ rannem ontogeneze [dissertation]. M., 1999.

8. Kopanev YuA, Sokolov AL. Disbakterioz kishechnika: microbiologicheskiye, immunologicheskiye i klinicheskiye aspekty mikroekologicheskikh narusheniy u detey. M., 2002.

9. Stepurina OV. Pervichnoye infitsirovaniye rebenka. Infektsionnyye zabolevaniya detey i ekologiya cheloveka. Stavropol', 1999; 92-7.

10. Frolova NA. Osobennosti formirovaniya mikrobiotsenoza u detey rannego vozrasta $v$ zavisimosti ot mikrobnogo peyzazha kishechnika materi [dissertation]. Smolensk, 2001

11. Nikitenko VI, Tkachenko El, Stadnikov AA. Translokatsiya bakteriy iz zheludochno-kishechnogo trakta - yestestvennyy zashchitnyy mekhanizm. Eksper i kiln gastroentorolog. 2004; (1): 48.

12. Funkhouser LJ, Bordenstein SR. Mom knows best: the universality of maternal microbial transmission. PLoS Biol. 2013;
(11): e1001631

13. Muglia LJ, Katz M. The enigma of spontaneous preterm birth. $\mathrm{N}$ Engl J Med. 2010; 362: 529-35.

14. Onderdonk AB, Hecht JL, McElrath TF, Delaney ML, Allred EN, Leviton A. Colonization of second-trimester placenta parenchyma. Am J Obstet Gynecol. 2008; 199: 51-2.

15. Solov'yeva IV, Belova IV, Tochilina AG, Efimov El, Pozhidaeva AS. Formirovaniye mikroflory tolstoy kishki u detey. Mikrobiologicheskiy i epidemiologicheskiy vestnik Nizhegorodskogo universiteta imeni N. I. Lobachevskogo. 2012; (2-3): 93-9.

16. Fanaro S, Chierici R, Guerrini P, Vigi V. Intestinal microflora in early infancy: composition and development. Acta pediat. 2003; 91 (441): 48-55.

17. Orrhagt $\mathrm{K}$, Nord $\mathrm{CE}$. Factors controlling the bacterial colonization of the intestine in breastfed infants. Acta Pediatr. 1999; 88 (430): 47-57.

18. Edwards CA, Parret AM. Intestinal flora during the first months of life: new perspectives. Br J Nutr. 2002; 88 (11): 11-8.

19. Goldman AS. Modulation of the gastrointestinal tract of infants by human milk. Interfaces and interactions. An evolutionary perspective. J Nutr. 2000; 130 (2): 426-31.

20. Netrebenko OK. Pitaniye grudnogo rebenka i kishechnaya mikroflora. Pediatriya. 2005; (3): 53-57.

21. Tkachenko El, Suvorova AN, editors. Disbioz kishechnika. Rukovodstvo po diagnostike i lecheniyu. SPb. InformMed, 2009; $276 \mathrm{p}$.

22. Shabalov NP. Neonatologiya. Moscow: Medpress-inform, 2004; p. 128-9.

23. Netrebenko OK. Pitaniye i razvitiye immuniteta $u$ detey na raznykh vidakh vskarmlivaniya. Pediatriya. Zhurnal imeni G. N. Speranskogo. 2005; (6): 50-6.

24. Pechkurov DV, Turti TV, Belyaeva IA, Tjazheva AA. Intestina 
microflora in children: from formation disturbances prophylaxis to preventing non-infectious diseases. Pediatric pharmacology.
2016; 13 (4): 377-83.

25. Suvorov AN. Mikrobiota detey. Priroda. 2011; (8): 14-21.

\section{Литература}

1. ОСТ 91500.11.0004-2003. Протокол ведения больных. Дисбактериоз кишечника. Утв. Приказом МЗ РФ № 231 от 09.06.2003. Москва, 2003; 173 с.

2. Методические рекомендации «Бактериологическая диапностика дисбактериоза кишечника». Минздрав РСФСР. 1977.

3. Методические рекомендации «Микробиологическая диагностика дисбактериоза кишечника». Москва, 2007.

4. Gronlund MM. Arvilommi H, Kero P, Lehtonen OP, Isolauri E. Importance of intestinal colonization in the maturation of humoral immunity in early infancy: a prospective follow up study of healthy infants aged 0-6 months. Arch Dis Child Fetal Neonatal. 2000; 83 (3): 186-92.

5. Леванова Л.А. Микроэкология кишечника жителей Западной Сибири, коррекция дисбиотических состояний [диссертация]. М., 2003.

6. Щербаков П. Л., Нижевич А. А., Логиновская В. В., Щербакова М. Ю., Кудрявцева Л. В., Митрохин С. Д. и др. Микроэкология кишечника у детей и ее нарушения. Фарматека. 2007; (14): 28-34.

7. Акоев Ю. С. Функциональные особенности недоношенных детей в раннем онтогенезе [диссертация]. М., 1999.

8. Копанев Ю. А., Соколов А. Л. Дисбактериоз кишечника: микробиологические, иммунологические и клинические аспекты микроэкологических нарушений у детей. М., 2002.

9. Степурина О. В. Первичное инсицирование ребенка. Инфекционные заболевания детей и экология человека. Ставрополь, 1999; 92-7.

10. Фролова Н. А. Особенности формирования микробиоценоза у детей раннего возраста в зависимости от микробного пейзажа кишечника матери [диссертация]. Смоленск, 2001.

11. Никитенко В. И., Ткаченко Е. И., Стадников А. А. Транслокация бактерий из желудочно-кишечного тракта - естественный защитный механизм. Эксперимент. и клин. гастроэнтерол. 2004; (1): 48.

12. Funkhouser LJ, Bordenstein SR. Mom knows best: the universality of maternal microbial transmission. PLoS Biol. 2013; (11): e1001631.

13. Muglia LJ, Katz M. The enigma of spontaneous preterm birth. $\mathrm{N}$ Engl J Med. 2010; 362: 529-35.

14. Onderdonk AB, Hecht JL, McElrath TF, Delaney ML, Allred EN, Leviton A. Colonization of second-trimester placenta parenchyma. Am J Obstet Gynecol. 2008; 199: 51-2.

15. Соловьева И. В., Белова И. В., Точилина А. Г., Ефимов Е. И., Пожидаева А.С. Формирование микрофлоры толстой кишки у детей. Микробиологический и эпидемиологический вестник Нижегородского университета им. Н. И. Лобачевского. 2012; (2-3): 93-9.

16. Fanaro S, Chierici R, Guerrini P, Vigi V. Intestinal microflora in early infancy: composition and development. Acta pediat. 2003; 91 (441): 48-55.

17. Orrhagt K, Nord CE. Factors controlling the bacterial colonization of the intestine in breastfed infants. Acta Pediatr. 1999; 88 (430): 47-57.

18. Edwards CA, Parret AM. Intestinal flora during the first months of life: new perspectives. Br J Nutr. 2002; 88 (11): 11-8.

19. Goldman AS. Modulation of the gastrointestinal tract of infants by human milk. Interfaces and interactions. An evolutionary perspective. J Nutr. 2000; 130 (2): 426-31.

20. Нетребенко О. К. Питание грудного ребенка и кишечная микрофлора. Педиатрия. 2005; (3): 53-7.

21. Ткаченко Е. И., Суворова А. Н., редакторы. Дисбиоз кишечника. Руководство по диагностике и лечению. СПб. ИнформМед, 2009; 276 c.

22. Шабалов Н. П. Неонатология. М.: Медпресс-информ, 2004; c. 128-29.

23. Нетребенко О. К. Питание и развитие иммунитета у детей на разных видах вскармливания. Педиатрия. Журнал им. Г. Н. Сперанского. 2005; (6): 50-6.

24. Печкуров Д. В., Турти Т. В., Беляева И. А., Тяжева А. А. Микробиота кишечника у детей: от профилактики нарушений становления к предупреждению неинфекционных заболеваний. Педиатрическая фармакология. 2016; 13 (4): 377-83.

25. Суворов А. Н. Микробиота детей. Природа. 2011; (8): 14-21. 